\title{
MATH DIDACTIC: JURNAL PENDIDIKAN MATEMATIKA
}

Volume 4 Nomor 1, Januari - April 2018, halaman 1 - 10

Tersedia Daring pada http://jurnal.stkipbjm.ac.id/index.php/math

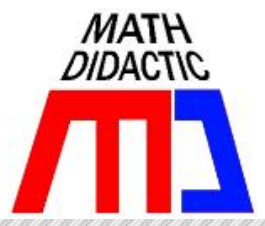

\section{PEMBELAJARAN INKUIRI TERBIMBING DALAM PEMBELAJARAN SEGIEMPAT} UNTUK MENINGKATKAN KEMAMPUAN PENALARAN MATEMATIS SISWA SMP

\author{
GUIDED INQUIRY LEARNING ON RECTANGULAR MATERIAL TO INCREASE \\ MATHEMATICAL REASONING ABILITY FOR JUNIOR HIGH SCHOOL STUDENTS
}

\author{
Abdul Jabar, Dina Lestari \\ STKIP PGRI Banjarmasin \\ abduljabar@stkipbjm.ac.id
}

\begin{abstract}
Abstrak: Pembelajaran matematika di sekolah saat ini masih sebatas sebagai proses penyampaian pengetahuan tetang matematika. Di lain sisi, anggapan bahwa matematika adalah mata pelajaran yang sulit mengakibatkan siswa menjadi malas belajar matematika dan rendahnya keterlibatan siswa dalam proses pembelajaran Untuk lebih memberikan memberikan kesempatan yang luas kepada siswa agar aktif belajar sekarang ini berkembang model-model pembelajaran. Salah satu model pembelajaran Inkuiri Terbimbing yang dapat membuat siswa aktif dalam memecahkan masalah. Tujuan penilitian ini adalah untuk mengetahui kemampuan penalaran matematis siswa pada materi segi empat di kelas VIIC SMP Negeri 2 Kandangan tahun pelajaran 2016/2017 dengan model Pembelajaran Inkuiri Terbimbing. Penelitian ini dilakukan dengan menggunakan penelitian tindakan kelas (PTK) dalam 2 siklus dengan 6 kali pertemuan. Subjek penelitian ini adalah siswa kelas VIIC SMP Negeri 2 Kandangan dengan jumlah siswa 25 orang yang terdiri 15 orang laki-laki dan 10 orang perempuan, dan objek dalam penelitian ini kemampuan penalaran matematis, teknik pengumpulan data yang digunakan tes. Teknik analisis data dalam penelitian ini menggunakan nilai rata-rata dan persentase.Hasil penelitian pada pembelajaran segiempat dengan menggunakan model Inkuiri Terbimbing pada siswa kelas VIIC SMP Negeri 2 Kandangan menunjukkan kemampuan penalaran matematis siswa meningkat dari kualifikasi cukup di siklus I menjadi kualifikasi baik sekali pada siklus II.
\end{abstract}

Kata Kunci: inkuiri terbimbing, segiempat, penalaran matematis

\begin{abstract}
Mathematics learning in schools today is still limited as a process of delivering knowledge about mathematics. On the other hand, the assumption that mathematics is a difficult subject causes students to be lazy to learn mathematics and the low involvement of students in the learning process To give more opportunities for students to actively learn now developing models of learning. One of the guided Inquiry learning models that can make students active in solving problems. The purpose of this research is to know the students' mathematical reasoning ability in rectangular material in class VIIC SMP Negeri 2 Kandangan 2016/2017 lesson year with Guided Inquiry learning model. This study was conducted using classroom action research (PTK) in 2 cycles with 6 meetings. The subjects of this study were students of class VIIC SMP Negeri 2 Kandangan with the number of students 25 people consisting of 15 men and 10 women, and objects in this study the ability of mathematical reasoning, data collection techniques used tests. Technique of data analysis in this research use mean value and percentage.Research result in quadrilateral study by using Guided Inquiry model on class VIIC student of SMP Negeri 2 Kandangan show student's mathematical reasoning ability increase from qualification enough in cycle I become qualification well once in cycle II.
\end{abstract}

Keywords: guided inquiry, rectangular, mathematical reasoning

Cara sitasi: Jabar, A., \& Lestari, D. (2018). Pembelajaran inkuiri terbimbing dalam pembelajaran matematika untuk meningkatkan kemampuan penalaran matematis siswa SMP. Math Didactic: Jurnal Pendidikan Matematika, 4(1), 1-10. 
Seiring dengan berkembangnya ilmu pengetahuan dan teknologi, manusia dituntut memiliki kemampuan berpikir kritis, sistematis, logis, kreatif, bernalar, dan bekerjasama secara efektif sehingga dapat berkembang maju di masa globalisasi ini. Berdasarkan kemampuan-kemampuan yang dimiliki tersebut, manusia dapat memanfaatkan informasi-informasi dari berbagai sumber menjadi sesuatu yang berguna dalam kehidupan. Ruseffendi (2001) menyatakan bahwa matematika terbentuk sebagai hasil pemikiran manusia yang berhubungan dengan ide, proses dan penalaran.Hal ini sejalan dengan tujuan pembelajaran matematika di sekolah, yaitu melatih cara berpikir dan bernalar dalam menarik kesimpulan, mengembangkan kemampuanmemecahkan masalah, serta mengembangkan kemampuan menyampaikan informasi atau mengkomunikasikan ide-ide melalui lisan, tulisan, gambar, grafik, peta, diagram, dan sebagainya.

Berdasarkan hasil wawancara dengan guru mata pelajaran matematika di kelas VIIC SMP Negeri 2 Kandangan, nilai ulangan harian tahun ajaran 2015-2016 pada materi segiempat diperoleh hasil yang menunjukan banyaknya siswa dikelas VIIC nilai ulangannya kurang dari KKM yaitu 70 sebanyak 15 siswa dari 25 siswa. Rendahnya nilai siswa ini menunjukkan bahwa kemampuan bernalar matematis siswa masih rendah. Berdasarkan informasi guru dari faktor siswa diperoleh bahwa siswa bekerja secara individual, sebagian siswa kurang aktif dalam kegiatan pembelajaran dan sebagian siswa kurang berminat pada pelajaran matematika. Dari sisi siswa faktor guru diperoleh informasi bahwa guru kurang mengkondisikan siswa untuk belajar secara kelompok, guru lebih sering menggunakan pembelajaran dengan model pembelajaran langsung. Pada pembelajran tersebut guru lebih sering menjelaskan suatu materi kemudian memberi contoh soal dan siswa diminta untuk mengerjakan soal-soal tersebut. Sehingga peran guru lebih dominan dari pada peran siswa.

Indrawati (1999) menyatakan, bahwa suatu pembelajaran pada umumnya akan lebih efektif bila diselenggarakan melalui modelmodel pembelajaran yang termasuk rumpun pemrosesan informasi. Hal ini dikarenakan model-model pemrosesan informasi menekankan pada bagaimana seseorang berpikir dan bagaimana dampaknya terhadap cara-cara mengolah informasi. Salah satu yang termasuk dalam model pemrosesan informasi adalah model pembelajaran inkuiri terbimbing (Guided Inquiry).

Model pembelajaran inkuiri terbimbing adalah rangkaian kegiatan pembelajaran yang menekankan pada proses berfikir secara kritis dan analitis untuk mencari dan menemukan sendiri jawaban dari suatu masalah yang dipertanyakan (Sanjaja,2006). Model inkuiri terbimbing menekankan pada keterlibatan siswa dalam pengamatan, penyelidikan peristiwa, persoalan dan fenomena yang telah ditetapkan dalam rencana pembelajaran, dan siswa diberi kesempatan untuk menggunakan pengetahuannya dalam penyelidikan (Olibie \& Ezeoba, 2014). Inkuiri terbimbing mendukung siswa untuk mengambil tanggung jawab penuh dalam pembelajaran melalui partisipasi mereka dalam egiatan eksperimen dan peran guru hanya sebagai pembimbing dan pendukung (Almuntasheri et al, 2016).

Hasil penelitian Ghani (2007) terhadap siswa SMA di Kabupaten Pidie-Aceh menunjukkan bahwa siswa yang belajardengan menggunakan pembelajaran inkuiri terbimbing model Alberta mengalami 
peningkatan kemampuan pemahaman dan pemecahan masalah yang lebih baik dibandingkan dengan menggunakan pembelajaraninkuiri bebas dan metode ekspositori.Selain itu, respon yang diberikan siswa terhadap pembelajaran inkuiri terbimbing model Alberta menunjukkan respon yang positif. Hal ini dikuatkan lagi dengan penelitian Ati Sukmawati (2014) yang dilakukan pada siswa kelas X SMK Negeri 4 Banjarmasin bahwa rata-rata kemampuan penalaran matematis siswa yang belajar dengan model pembelajaran inkuiri terbimbing dan pembelajaran konvensional berbeda secara signifikan. Tingkat perkembangan rata-rata kemampuan penalaran matematis siswa yang belajar dengan model pembelajaran inkuiri terbimbing lebih tinggi dibandingkan dengan siswa yang belajar dengan pembelajaran konvensional.

Sanjaja (2006) menyatakan bahwa yang melaksanakan pembelajaran inkuiri mengikuti langkah-langkah sebagai berikut : (1) Orientasi. Langkah orientasi adalah langkah untuk membina suasana atau iklim pembelajaranyang responsif. (2) Merumuskan masalah. Merumuskan masalah merupakan langkah membawa siswa pada suatu persoalan. Persoalan yang disajikan adalah persoalan yang menantang siswa untuk berpikir memecahkan masalah. (3) Merumuskan hipotesis. Hipotesis adalah jawaban sementsra dari suatu permasalahan yang sedang dikaji. Sebagai jawaban sementara, hipotesis perlu diuji kebenarannya (4) Mengumpulkan data. Mengumpulkan data adalah aktivitas menjaring informasi yang dibutuhkan untuk menguji hipotesis yang diajukan. (5) Menguji hipotesis. Menguji hipotesis adalah proses menentukan jawaban yang dianggap diterima sesuai dengan data atau informasi yang diperoleh berdasarkan pengumpulan data. Yang terpenting dalam menguji hipotesis adalah mencari tingkat keyakinan siswa atas jawaban yang diberikan. (6) Merumuskan kesimpulan. Meremuskan kesimpulan adalah proses mendeskripsikan temuan yang diperoleh berdasarkan hasil pengujian hipotesis.

Keunggulan model pembelajaran inkuiri terbimbing (Sanjaja: 2006): (1) Inkuiri terbimbing merupakan model pembelajaran yang menekankan kepada pengembangan aspek kognitif, afektif, dan psikomotor secara seimbang, sehingga pembelajaran melalui strategi ini di anggap lebih bermakna . (2) Model pembelajaran inkuiri terbimbing dapat memberikan ruang kepada siswa untuk belajar sesuai dengan gaya belajar mereka.(3) Model pembelajaran inkuiri terbimbing merupakan model yang dianggap sesuai dengan perkembangan psikologi belajar modern yang menganggap belajar adalah proses perubahan tingkah laku berkat adanya pengalaman. (4) Keuntungan lain adalah model pembelajaran ini dapat melayani kebutuhan siswa yang memiliki kemampuan diatas rata-rata. Artinya, siswa yang memiliki kemampuan belajar bagus tidak akan terhambat oleh siswa yang lemah dalam belajar.

Menurut KBBI (2017), kata kemampuan berasal dari kata mampu yang berarti kuasa, sanggup melakukan sesuatu atau dapat. Kemudian mendapatkan imbuhan ke-an sehingga kata kemampuan berarti kesanggupan melakukan sesuatu hal. Kemampuan adalah kapasitas seorang individu untuk melakukan beragam tugas dalam suatu pekerjaan.

Menurut Soekadijo (1997) menyatakan bahwa penalaran merupakan suatu proses menarik kesimpulan sebuah proposisi baru yang sebelumnya tidak diketahui, berdasarkan 
sejumlah proposisi yang diketahui atau dianggap benar. Menurut Shadiq (2004) penalaran merupakan suatu kegiatan, suatu proses atau suatu aktivitas berpikir untuk menarik kesimpulan atau membuat suatu pernyataan baru yang benar berdasar pada beberapa pernyataan yang kebenarannya telah dibuktikan atau diasumsikan sebelumnya. Dari uraian di atas dapat disimpulkan bahwa penalaran merupakan suatu kegiatan, suatu proses atau suatu aktivitas berpikir yang sistematik untuk menarik kesimpulan atau membuat suatu pernyataan baru yang benar berdasar pada beberapa pernyataan yang kebenarannya telah dibuktikan atau diasumsikan sebelumnya.

Menurut Sri Wardani (2008) menyatakan bahwa ada dua cara untuk menarik kesimpulan yaitu secara induktif dan deduktif, sehingga dikenal istilah penalaran induktif dan penalaran deduktif. Penalaran induktif adalah proses yang berpangkal dari peristiwa yang khusus yang dihasilkan berdasarkan hasil pengamatan impirik dan menghasilkan suatu kesimpulan atau pengetahuan yang bersifat umum. Penalaran Deduktif merupakan proses berpikir untuk menarik kesimpulan tentang hal khusus yang berpijak pada hal umum atau hal yang sebelumny telah dibuktikan (diasumsikan) kebenarannya.

Dengan demikian kemampuan penalaran matematis adalah salah satu proses berfikir yang dilakukan dengan cara menarik suatu kesimpulan dimana kesimpulan tersebut merupakan kesimpulan yang sudah valid atau dapat dipertanggung jawabkan. salah satu tujuan terpenting dari pembelajaran matematika adalah mengajarkan kepada siswa penalaran logika. Bila kemampuan bernalar tidak dikembangkan pada siswa, maka bagi siswa matematika hanya akan menjadi materi yang mengikuti serangkaian prosedur dan meniru contoh-contoh tanpa mengetahui maknanya. Pada dasarnya setiap penyelesaian soal matematika memerlukan kemampuan penalaran. Melalui penalaran, siswa diharapkan dapat melihat bahwa matematika merupakan kajian yang masuk akal atau logis. Dengan demikian siswa merasa yakin bahwa matematika dapat dipahami, dipikirkan, dibuktikan, dan dapat dievaluasi. Dan untuk mengerjakan hal-hal yang berhubungan diperlukan bernalar.

Penjelasan teknis Peraturan Dirjen Dikdasmen yang dikutip (Sri Wardani: 2005) tentang penilaian perkembangan anak didik SMP dicantumkan indikator dari kemampuan penalaran sebagai hasil belajar matematika, yaitu siswa mampu: (1) Mengajukan dugaan. Kemampuan mengajukan dugaan merupakan kemampuan siswa dalam merumuskan berbagai kemungkinan pemecahan sesuai dengan pengetahuan yang dimilikinya. (2) Melakukan manipulasi matematika. Kemampuan manipulasi matematika merupakan kemampuan siswa dalam mengerjakan atau menyelesaikan suatu permasalahan dengan menggunakan cara sehingga tercapai tujuan yang dikehendaki. (3) Menarik kesimpulan, menyusun bukti, memberikan alasan atau bukti terhadap kebenaran solusi. Siswa mampu menarik kesimpulan, menyusun bukti, memberikan alasan atau bukti terhadap kebenaran solusi apabila siswa mampu menunjukkan lewat penyelidikan. (4) Menarik kesimpulan dari pernyataan. Kemampuan menarik kesimpulan dari pernyataan merupakan proses berpikir yang memberdayakan pengetahuannya sedemikian rupa untuk menghasilkan sebuah pemikiran. (5) Memeriksa kesahihan suatu argumen. Kemampuan memeriksa kesahihan suatu argumen merupakan kemampuan yang 
menghendaki siswa agar mampu menyelidiki tentang kebenaran dari suatu pernyataan yang ada. (6) Menemukan pola atau sifat dari gejala matematis untuk membuat generalisasi.

Tujuan peniulitian ini adalah untuk mengetahui kemampuan penalaran matematis siswa pada materi segi empat di kelas VIIC SMP Negeri 2 Kandangan tahun pelajaran 2016/2017 dengan model Pembelajaran Inkuiri Terbimbing.

Berdasarkan pembahasan di atas maka hipotesis tindakan yang dirumuskan dalam penelitian ini adalah penggunaan model pembelajaran inkuiri terbimbing dapat meningkatkan kemampuan penalaran matematis siswa kelas VIIC SMP Negeri 2 Kandangan Tahun Pelajaran 2016/2017 pada mata materi segi empat

\section{Metode Penelitian}

Penelitian ini merupakan penelitian tindakan kelas (PTK). Menurut Arikunto (2010) PTK adalah suatu penelitian yang dilakukan di kelas dengan tujuan memperbaiki/meningkatkan mutu praktik pembelajaran. Desain penelitian tindakan kelas ini menggunakan model siklus Kemmis dan Mc Taggart (Arikunto, 2010). Penelitian tindakan kelas ini terdiri dari dua siklus, yaitu siklus pertama dan siklus kedua. Siklus pertama terdiri dari empat langkah, yaitu perencanaan, tindakan, pengamatan dan refleksi. Kemudian apabila terdapat hambatan pada siklus pertama tersebut, maka dilakukanlah revisi perencanaan untuk diterapkan pada siklus kedua agar lebih meyakinkan dan menguatkan hasil dari penerapan model inkuiri terbimbing ini. Adapun model yang dimaksud yang menggambarkan empat langkah tersebut disajikan dalam Gambar 1.

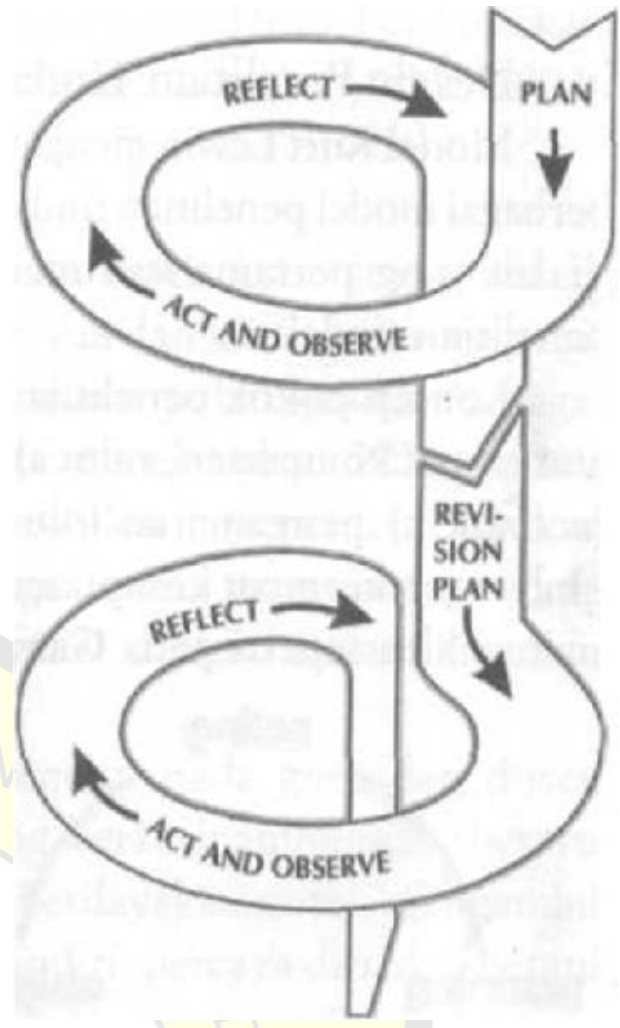

Gambar 1. Siklus Penelitian Tindakan Kelas Model Kemmis dan Mc. Taggart

Subjek dalam penelitian ini adalah siswa kelas VIIC SMP Negeri 2 Kandangan tahun pelajaran 2016/2017 sebanyak 25 orang. Objek peneliti adalah kemampuan penalaran matematis siswa kelas VIIC SMP Negeri 2 Kandangan tahun Pelajaran 2016/2017 pada pokok bahasan Segiempat.

Teknik yang digunakan untuk mengumpulkan data dalam penelitian ini adalah Tes, teknik ini dilakukan dengan memberikan tes hasil belajar kepada siswa yaitu berupa ulangan harian sebagai evaluasi disetiap akhir siklus. Dalam penelitian ini soal yang digunakan soal berbentuk uraian yang berjumlah 4 soal pada siklus pertama dan 4 soal uraian pada siklus ke 2 .

Perhitungan kemampuan penalaran siswa diambil dari skor pada tes akhir siklus, untuk setiap langkah jawaban benar diberi skor 1 dan salah diberi skor 0. Kemampuan penalaran yang diteliti dalam penelitian ini 
adalah mengajukan dugaan, melakukan manipulasi matematika., menarik kesimpulan, memeriksa kesahihan suatu argument, danmenemukan pola atau sifat dari gejala matematis untuk membuat generalisasi. Adapun perhitungan hasil belajar siswa secara individual menurut Usman dan Setiawati (2001: 34) dihitung dengan rumus:

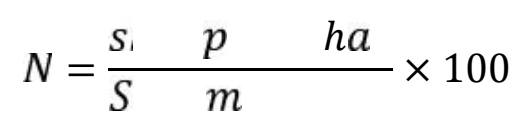

Keterangan:

$N=$ nilai

Selanjutnya dihitung nilai rata-ratanya dengan menggunakan rumus:

$$
\bar{x}=\frac{1}{n} \sum_{i=1}^{n} x_{i}
$$

\section{Keterangan:}

$\bar{x}=$ nilai rata-rata

$x_{i}=$ nilai $\mathrm{ke}-\mathrm{i}$

$\mathrm{n}$ = banyak data

Nilai rata-rata yang diperoleh siswa kemudian diinterpretasikan menggunakan kualifikasi padatabel berikut:

Tabel 1. KualifikasiKemampuan Penalaran Matematis Siswa

\begin{tabular}{clccc}
\hline No & Skor & $\begin{array}{c}\text { Nilai } \\
\text { Huruf }\end{array}$ & Keterangan \\
\hline $\mathbf{1}$ & $80 \leq N \leq 100$ & $\mathrm{~A}$ & Baik Sekali \\
$\mathbf{2}$ & $70 \leq N<80$ & $\mathrm{~B}$ & Baik \\
$\mathbf{3}$ & $60 \leq N<70$ & $\mathrm{C}$ & Cukup \\
$\mathbf{4}$ & $50 \leq N<60$ & $\mathrm{D}$ & Kurang \\
$\mathbf{5}$ & $0 \leq N<50$ & $\mathrm{E}$ & Gagal \\
\hline
\end{tabular}

(Sumber: Azwar 2010)

Kemudian mengetahui persentasi siswa yang memenuhi KKM digunakan rumus berikut:

$$
p=\frac{f}{N} \times 100 \%
$$

Keterangan:

$f=$ frekuensi yang sedang dicari persentasenya

$\mathrm{N}=$ Number of Cases (jumlah frekuensi/banyaknya individu)

$p$ =angka persentase. (Sudijono: 2008)

Indikator keberhasilan dalam PTK ini adalah (1) rata-rata kemampuan penalaran matematis siswa minimal berada pada kualifikasi Baik. (2) Tuntas secara klasikal, yakni $85 \%$ siswa memiliki kemampuan matematis minimal berada kualifikasi Baik

\section{Hasil Penelitian dan Pembahasan}

\section{Hasil}

Pembelajaran pada siklus I dilaksanakan dalam 3 kali pertemuan, terdiri dari 2 kali pertemuan pembelajaran dan 1 kali evaluasi. Pelaksanaan penelitian ini berlangsung pada tanggal 20, 25, dan 27 Maret 2017. Pada pertemuan pertama siswa mempelajari materi tentang sifat-sifat persegi panjang, persegi, jajargenjang, belah ketupat, layang-layang, dan trapesium. Pada pertemuan kedua siswa mempelajari keliling dan luas persegi panjang dan persegi. Pada pertemuan ketiga dilakukan tes evaluasi tahap ini.

Berikut disajikan hasil tes yang menunjukkan kemampuan penalaran matematis siswa, diperoleh hasil seperti pada tabel 2 Berikut.

Tabel 2 Kemampuan Penalaran Matematis Siswa Siklus I

\begin{tabular}{rllll}
\hline Nilai & Kualifikasi & F & $\begin{array}{l}\text { Presentase } \\
(\boldsymbol{\%})\end{array}$ \\
\hline $\mathbf{8} \leq \boldsymbol{N} \leq \mathbf{1}$ & Baik Sekali & 2 & $8 \%$ \\
$7 \leq \boldsymbol{N}<\mathbf{8}$ & Baik & 13 & $52 \%$ \\
$\mathbf{6} \leq \boldsymbol{N}<\mathbf{7}$ & Cukup & 1 & $4 \%$ \\
$\mathbf{5} \leq \boldsymbol{N}<\mathbf{6}$ & Kurang & 6 & $24 \%$ \\
\hline
\end{tabular}




\begin{tabular}{clll}
\hline $\mathbf{0} \leq \boldsymbol{N}<\mathbf{5}$ & Gagal & 3 & $12 \%$ \\
Jumlah & & 25 & $100 \%$ \\
\hline
\end{tabular}

Pembelajaran pada siklus II dilaksanakan dalam 3 kali pertemuan juga. Tahapan-tahapan pada siklus II ini dilaksanakan sesuai dengan tahapan-tahapan yang telah ditetapkan pada RPP dengan menghitung keliling dan luas bangun segiempat serta menggunakannya dalam pemecahan masalah dengan model pembelajaran inkuri terbimbing. Berikut disajikan kemampuan penalaran matematis siswa dengan menggunakan tes akhir siklus II

Tabel 3Kemampuan Penalaran Matematis Siswa Siklus II

\begin{tabular}{clll}
\hline Nilai & Kualifikasi & F & $\begin{array}{l}\text { Presentase } \\
(\%)\end{array}$ \\
\hline $\mathbf{8} \leq \boldsymbol{N} \leq \mathbf{1}$ & Baik Sekali & 10 & $40 \%$ \\
$7 \leq \boldsymbol{N}<\mathbf{8}$ & Baik & 12 & $48 \%$ \\
$\mathbf{6} \leq \boldsymbol{N}<\mathbf{7}$ & Cukup & 1 & $4 \%$ \\
$\mathbf{5} \leq \boldsymbol{N}<\mathbf{6}$ & Kurang & 1 & $4 \%$ \\
$\mathbf{0} \leq \boldsymbol{N}<\mathbf{5}$ & Gagal & 1 & $4 \%$ \\
\hline Jumlah & & 25 & $100 \%$ \\
\hline
\end{tabular}

\section{Pembahasan}

Berdasarkan Tabel 2 kemampuan penalaran matematis siswa pada siklus I dengan menggunakanmodel pembelajaran inkuri terbimbing yang diperoleh dari hasil tes akhir siklus hanya 15 siswa yang mencapai KKM dan 10 siswa belum mencapai KKM dengan nilai rata-rata kemampuan siswa yaitu 69,69 berada pada kualifikasi cukup.

Adapun hal-hal yang perlu direfleksikan pada siklus I ini adalah: (1) Dalam proses pembelajaran masih ada beberapa siswa yang masih belum mampu membuat kesimpulan akhir dari hasil temuannya. Tindakan yang dilakukan adalah dengan meminta siswa untuk mempelajari yang akan dipelajari pada pertemuan selanjutnya.(2) Siswa masih malu-malu untuk mempresentasikan hasil diskusi kelompok di depan kelas. Tindakan yang dapat dilakukan adalah dengan memberikan motivasi kepada siswa untuk berani tampil didepan kelas. Motivasi yang dapat diberikan dapat berupa tepuk tangan atau hadiah untuk kelompok yang paling aktif. (3) Dalam proses pembelajaran masih ada beberapa siswa yang kurang teliti dan bahkan ada yang lupa cara menggunakan busur derajat. Tindakan yang dapat dilakukan adalah dengan memberikan bantuan dan bimbingan kepada siswa yang masih belum bisa menggunakan menggunakan busur derajat dan kurang teliti dalam pengukuran. (4) Masih ada sebagian siswa yang kurang aktif dalam kegiatan kelompok. Tindakan yang dapat dilakukan adalah dengan cara memberikan pemahaman kepada siswa pada awal pembelajaran bahwa setiap anggota kelompok harus merasa menjadi bagian dari kelompok dan harus bisa berkerjasama agar tujuan pembelajaran dapat tercapai.

Berdasarkan Tabel 3 diatas kemampuan penalaran matematissiswa pada siklus II dengan menggunakan model pembelajaran inkuri terbimbing terdapat 22 siswa yang mencapai KKM dan 3 siswa belum mencapai KKM dengan rata-rata 80,96 berada pada kualifikasi baik. Ini artinya secaraklasikal sudah memenuhi indikator keberhasilan penelitian, Dapat disimpulkan bahwa kemampuan penalaran matematissiswa di kelas VIIC SMP Negeri 2 Kandangan meningkat.

Hasil penelitian menunjukkan bahwa pembelajaran dengan model inkuri terbimbing dapat meningkatkan kemampuan penalaran matematissiswa. Hal ini ditunjukkan dari hasil tes akhir siklus I dengan rata-rata nilai 69,69 
dan ketuntasan individual hanya $60 \%$ dan pada siklus II terjadi peningkatan hasil belajarnya rata-rata nilai 80,96 dan ketuntasan klasikal adalah $88 \%$. Hal ini dikarenakan siswa sudah lebih memiliki kemampuan penalaran matematis yang baik. Peningkatan ini dapat dilihat pada diagram 1 berikut.

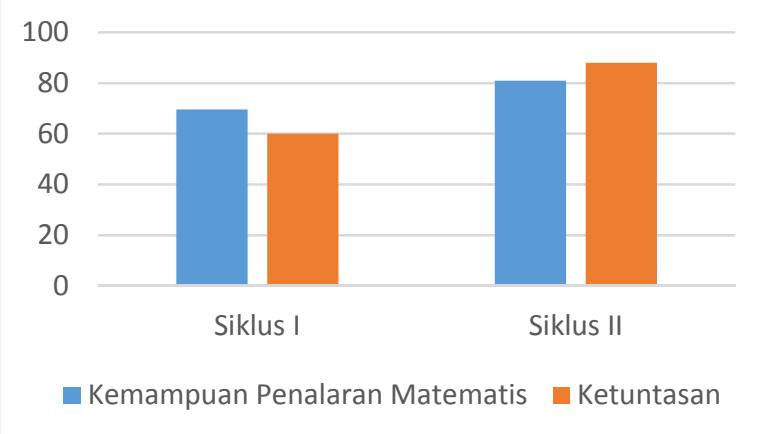

Peningkatan kemampuan penalaran matematis siswa dari siklus I dan siklus II, menunjukkan bahwa dengan menerapkan model inkuri terbimbing, hal ini menguatkan apa yang telah dilakukan oleh Ati $S$ (2014)yang menyatakan bahwa perkembangan rata-rata kemampuanpenalaran matematis siswa yang belajar dengan model pembelajaran inkuiriterbimbing akan semakin baik.

Adapun kekurangan pada saat penelitian dengan menggunakan model pembelajaran inkuiri terbimbing ditemukan pada pertemuan pertama yaitu kurangnya koordinasi secara bersamaan dari berbagai aktivitas antar kelompok dan banyak waktu yang tersita dengan pembentukan kelompok, yang disebabkan adanya ketidak cocokan antara siswa satu dengan yang lain, hal ini langsung diantisipasi oleh guru pengajar dengan memberikan pengertian kepada kelompok yang tidak merasa tidak cocok dengan rekan angota kelompok. Untuk mempermudah jalannya diskusi peneliti telah membagi kelompok secara heterogen. Beberapa kesulitan yang dialami oleh siswa adalah saat melakukan aktivitas manipulasi matematika. Ketika mereka mendapatkan fakta yang tidak sesuai faktanya dengan rumus mereka kebingungan

Kelebihan penggunaan model pembelajaran inkuiri terbimbing yang timbul pada saat penelitian, pelaksanaan yang mudah dalam setiap jenjang pendidikan dan dalam setiap kesempatan, waktu untuk berpikir untuk menigkatkan respon siswa, siswa dapat belajar dari siswa lain, dan yang terakhir siswa dalam kelompoknya mempunyai kesempatan untuk bekerja sama atau menyampaikan idenya. Berdasarkan hasil penelitian dan pembahasan tersebut maka hipotesis tindakan yang dirumuskan dalam penelitian ini dapat diterima yaitu penggunaan model pembelajaran inkuiri terbimbing dapat meningkatkan kemampuan penalaran matematis siswa kelas VIIC SMP Negeri 2 Kandangan Tahun Pelajaran 2016/2017 pada mata pelajaran Matematika

\section{Simpulan dan Saran}

\section{Simpulan}

Hasil penelitian pada pembelajaran segiempat dengan menggunakan model Inkuiri Terbimbing pada siswa kelas VIIC SMP Negeri 2 Kandangan menunjukkan kemampuan penalaran matematis siswa meningkat dari kualifikasi cukup di siklus I menjadi kualifikasi baik sekali pada siklus II.

\section{Saran}

Saran-saran yang dapat penulis kemukakan berkenaan dengan hasil penelitian adalah sebagai berikut.
a. Bagi Siswa 
Diharapkan bagi siswa untuk terlibat aktif dalam jalannya diskusi, memperhatikan dengan baik kelompok lain yang sedang mempresentasi dan percaya diri atas kemampuan sendiri.

b. Bagi Guru

Guru diharapkan dapat menerapkan Pembelajaran Inkuiri Terbimbing pada pembelajaran matematika dan sebagai salah satu alternatif dalam upaya meningkatkan hasil belajar siswa, lebih memperhatikan siswa yang mana kurang aktif dalam pembelajaran.

c. Bagi Sekolah

Hendaknya dengan menggunakan model Pembelajaran Inkuiri Terbimbing dapat meningkatkan kualitas dan alternatif pembelajaran disekolah.

Hendaknya para peneliti lain secara lebih yang berminat melaksanakan penelitian tindakan kelas dalam kaitan model Pembelajaran Inkuiri Terbimbing dapat menyusun bahan agar secara lebih efektif untuk memahamkan siswa terhadap materi pembelajaran. d. Bagi Peneliti Lain

Penalaran Matematis Siswa SMK. EDU-MAT Jurnal Pendidikan

Matematika, Volume 2, Nomor 3, Oktober 2014, hlm 202 - 210

Azwar, Saifuddin. 2010. Metode Penelitian. Yogyakarta: Pustaka Pelajar.

Ghani, R. A., 2007. Pengaruh PembelajaranMetode Inquiri Terbimbing ModelAlberta terhadap Kemampuan Pemahamandan Pemecahan MasalahMatematika Siswa SekolahMenengah Atas. Disertasi JurusanPendidikan MatematikaFPMIPAUPI. Diakses melaluihttp://digilib.upi.edu/. Pada tanggal 3 Februari 2017.

Indrawati. 1999. Keterampilan Proses Sains: Tinjauan Kritis dari Teori ke Praktis. Dirjen Pendidikan Dasar dan Menengah. Bandung.

KBBI. https://kbbi.web.id/mampu, di akses 3 Februari 2017

Olibie \& Ezeoba. 2014. Ability and Location Differences in the Effect of Guided Inquiry on Nigerian Students' Achievement in Social Studies Curriculum. Journal of Education and Human Development, Vol. 3. No. 4: 335-344.

Ruseffendi,E.T,2001.

PengantarKepadaMembantuGuruMen gembangkan

KompetensinyadalamPengajaranMate matikaUntuk Meningkatkan CBSA. Bandung. Tarsito

Teachers' Professional Development Programme on Saudi Students' Understanding of Density.Science Education International, Vol. 27. Issue 1: 16-39.

Arikunto, Suharsimi. dkk. 2010. Penelitian Tindakan Kelas. Jakarta: PT Bumi Aksara.

Ati, S \& Lilis, P. 2014. Penerapan Model Pembelajaran Inkuiri Terbimbing Dalam Pembelajaran Matematika Untuk Meningkatkan Kemampuan
Sanjaja, Wina. 2006 Strategi Pembelajaran Berorintasi Standar Proses Pendidikan. Jakarta: Kencana Prenada Media Grup. Shadiq, F. 2004. Pemecahan Masalah, Penalaran, dan Komunikasi. Makalah. Disampaikan dalam Diklat Instruktur/ Pengembang Matematika Jenjang Dasar. Yogyakarta: PPPG Matematika.(online) Tersedia pada : 
http//prints.uny.ac.id/181e2/1/SKRIPSI. pdf Diakses pada 17 September 2016 Soekadijo. 1997. Logika Dasar Tradisional, Simbolik, dan Induktif. Jakarta: Gramedia. (online). Tersedia pada : http//prints.uny.ac.id/181e2/1/SKRIPSI. pdf Diakses pada 17 September 2016

Sudijono, A. 2008. Pengantar Statistik Pendidikan. Jakarta: RajaGrafindo Persada 